\title{
FAKTOR RISIKO KEJADIAN GIZI KURANG PADA BALITA DI DESA GAYAMAN KECAMATAN MOJOANYAR MOJOKERTO
}

\author{
Eka Diah Kartiningrum \\ Dosen Politeknik Kesehatan Majapahit
}

\begin{abstract}
Malnutrition in children can cause growth disorders bodies, prone to illness, decreased level of intelligence and mental disturbance and even cause death of the child. Malnutrition can be caused by various factors, among others such as socioeconomic status, knowledge, completeness immunization, infectious diseases, exclusive breastfeeding and early initiation of breastfeeding. The purpose of this research to analyze the risk factors of malnutrition among children under five in the village Gayaman Mojosari Mojokerto. This research used observational analytic research with case - control approach and use 40toddlers as a sample then divided into two groups of samples of 20 infants with malnutrition status as both a case and 20 toddlers with good nutritional status as a control. The independent variable infectious disease history, mother's milk (ASI) exclusive, Early Initiation of Breastfeeding (IMD). The dependent variable is the nutritional status of infants.The relationship between a history of infections, exclusive breastfeeding, IMD and nutritional status were analyzed using logistic regression. The results showed that a history of infectious diseases, exclusive breastfeeding, and IMD influential in determining the incidence of malnutrition among children under five (with $R 2$ of 96.7\%). The third variable is a risk factor for the incidence of malnutrition among children under five (infection $O R=1.85 ;$ OR ASI $=1.47$ and $O R I M D=1.46$ ). Therefore, mothers with babies should have regard to the provision of early initiation of breastfeeding and exclusive breastfeeding the baby and continues to do preventive measures to prevent infections that babies and toddlers can grow with optimal nutritional status
\end{abstract}

Keyword: nutrient, status, child, risk

\section{A. PENDAHULUAN}

Kekurangan gizi pada anak dapat menimbulkan beberapa efek negatif seperti lambatnya pertumbuhan badan, rawan terhadap penyakit, menurunnya tingkat kecerdasan, dan terganggunya mental anak. Kekurangan gizi yang serius dapat menyebabkan kematian anak. Berbagai penelitian membuktikan lebih dari separuh kematian bayi dan balita disebabkan oleh keadaan gizi yang jelek. Resiko meninggal dari anak yang bergizi buruk 13 kali lebih besar dibandingkan anak yang normal. WHO memperkirakan bahwa 54\% penyebab kematian bayi dan balita didasari oleh keadaan gizi anak yang jelek (Suwiji,2006).

Menurut data WHO pada tahun 2012 kematian bayi dan balita di dunia disebabkan oleh pneumonia $19 \%$, diare $18 \%$, malaria $8 \%$, campak $4 \%$, HIV/AIDS 3\%, kondisi neonatal termasuk kelahiran prematur, asfiksia dan infeksi $37 \%$. Dari kematian bayi dan balita tersebut lebih dari 50\% nya menderita gizi kurang, oleh karena itu menurunkan kejadian gizi kurang berarti menurunkan angka kematian bayi dan balita. Pada tahun 2012, Indonesia merupakan negara kekurangan gizi nomor 5 di dunia. Peringkat kelima karena jumlah penduduk Indonesia juga di urutan empat terbesar dunia, Jumlah balita yang kekurangan gizi di Indonesia saat ini sekitar 900 ribu jiwa. Jumlah tersebut merupakan 4,5 persen dari jumlah balita Indonesia, yakni 23 juta jiwa. Daerah yang kekurangan gizi tersebar di seluruh Indonesia, tidak hanya daerah bagian timur Indonesia. Dinas Kesehatan (Dinkes RI, 2012). Kepala Litbangkes Kemenkes Trihono mengatakan, dari data Riskesdas 2013 kecendrungan di setiap provinsi pada 2013 balita kurang gizi berjumlah 19,6 persen hal ini naik dari 18,4 persen. Sedangkan daerah yang paling tinggi 
angka balita kekurangan gizi ialah NTT sekitar 34 persen. Saat ini, jumlah balita kurang gizi buruk 5,7 persen dan gizi kurang 13,9 persen. Sedangkan kecenderungan nasional 2013 proporsi anak yang kurus 6,8 persen sedangkan yang sangat kurus 5,3 persen (Kemenkes, 2014). Berdasarkan hasil survey Pemantauan Status Gizi (PSG) Keluarga Sadar Gizi (Kadarzi) tahun 2010 diketahui bahwa prevalensi gizi buruk di Jawa Timur adalah sebesar 2,5 \%. Sedangkan dari hasil laporan Kejadian Luar Biasa (KLB) gizi buruk tahun 2011 di Jawa Timur terdapat 6925 anak yang menderita gizi buruk. Menurut ketua umum penggerak PKK Jatim Nina Soekarwo di jawa Timur sampai tahun 2011, 20 persen anak balita dari total 2,4 juta anak balita mengalami gizi buruk (Dinkes RI, 2012). Angka kejadian gizi buruk di kabupaten Mojokerto mencapai sebanyak 76 penderita. Dari 76 penderita, pada tahun 2012 penderita gizi buruk yang meninggal 12 penderita. Data dinas kesehatan (Dinkes) Kota Mojokerto menunjukkan hingga bulan Nopember 2013 ada sebanyak 84 bayi di kota ini masuk kategori Bawah Garis Merah (BGM) (Dinkes Mojokerto, 2013). Hasil study pendahuluan yang dilakukan di Desa Gayaman, KecamatanMojoanyar, KabupatenMojokertopada tanggal 13 januari 2015, dengan menggunakan $7 \mathrm{ibu}$ balita sebagai responden. Ditemukan 3 balita dengan status gizi buruk (diantaranya 2 balita memiliki riwayat penyakit infeksi typus dan diare serta 1 balita tidak mendapatkan ASI eksklusif dan IMD) serta 2 balita dengan status gizi sedang dan 2 balita dengan status gizi baik.

Ada beberapa faktor yang mempengaruhi status gizi buruk pada balita diantaranya riwayat penyakit infeksi biasanya mengalami perubahan pola makan, sehingga terjadi ketidak seimbangan antara intake dan kebutuhan gizi tubuh. Jika hal ini terjadi dalam waktu yang cukup lama maka terjadilah gizi buruk. Penyakit infeksi yang sering diderita oleh anak dengan gizi buruk adalah diare dan ISPA. Kenyataan di lapangan menunjukkan bahwa anak gizi buruk dengan gejala klinis umumnya disertai dengan penyakit infeksi seperti diare, ISPA, tuberkulosis (TB) serta penyakit infeksi lainnya (Direktorat Bina Gizi Masyarakat, 2007). Menurut Supariasa (2012) menyatakan bahwa ada hubungan yang sangat erat antara infeksi (bakteri, virus, dan parasit) dengan malnutrisi. Mereka menekankan interaksi yang sinergis antara malnutrisi dengan penyakit infeksi dan juga infeksi akan mempengaruhi status gizi dan mempercepat malnutrisi (Gizi pada balita, 2010). Penelitian yang dilakukan Hadiyatmiko(2003)menyebutkan bahwa Bayi yang mendapatkan ASI ekslusif 0,3 kali beresiko menderita gizi kurang dibanding bayi yang tidak mendapatkan ASI eksklusif. Karena ASI merupakan sumber nutrisi utama bagi bayi. Dalam ASI terkandung semua zat gizi yang diperlukan oleh bayi sehingga dapat kita simpulkan bahwa dengan pemberian ASI eksklusif dapat menekan kejadian gizi buruk. IMD merupakan pemberian kesempatan pada bayi untuk langsung menyusui dengan mencari puting ibunya sendiri setelah lahir. Dengan melaksanakan IMD, tentunya angka kematian bayi akan menurun. Tak hanya itu, IMD juga besar manfaatnya terhadap keberhasilan menyusui dan memberi bayi kesempatan untuk belajar menemukan puting susu ibunya. IMD pun membantu bayi untuk menjaga kemampuan bertahan hidup secara alami. Pada jam pertama bayi menemukan payudara ibunya, ini awal hubungan menyusui berkelanjutan dalam kehidupan antara ibu dan bayi menyusu. Prosesnya setelah melakukan inisiasi menyusu dini maka dilanjutkan dengan pemberian ASI eksklusif selama 6 bulan dan diteruskan hingga dua tahun. Sehingga dengan dilakukannya IMD kebutuhan nutrisi bayi dapat terpenuhi (Khosim Soleh, 2008).

Penanggulangan masalah gizi buruk dilakukan dengan pendekatan yang menyeluruh dengan melibatkan semua pihak baik keluarga, masyarakat, pemerintah maupun pelaku ekonomi. Intervensi untuk mengatasi masalah gizi buruk terdiri atas tahap jangka pendek (darurat), jangka menengah, dan jangka panjang. Sebagai seorang perawat tentunya kita memiliki peran penting dalam masalah ini, banyak hal yang bisa kita upayakan untuk 
menekan angka kejadian gizi kurang di daerah wilayah binaan kita khususnya. Upaya tersebut antara lain : Mengidentifikasi masalah gizi pada suatu daerah, Pemberi pelayanan kesehatan difasilitas kesehatan dan pemberian edukasi tentang pemenuhan gizi pada warga yang rentan terhadap gizi buruk.

Dari uraian di atas peneliti tertarik untuk meneliti risiko kejadian gizi kurang pada balita di tinjau dari riwayat penyakit infeksi, ASI ekslusif dan IMD di Desa Gayaman, Kecamatan Mojosari, Kabupaten Mojokerto.

\section{B. TINJAUAN PUSTAKA}

\section{Definisi Gizi.}

Gizi adalah suatu proses penggunaan makanan yang dikonsumsi secara normal oleh suatu organisme melalui proses digesti, absorbsi, transportasi, penyimpanan, metabolisme dan pengeluaran zat-zat yang tidak digunakan untuk mempertahankan kehidupan, pertunbuhan dan fungsi normal dari organ-organ, serta menghasilkan energi (Atikah, 2009:1). Status Gizi adalah status kesehatan yang dihasilkan oleh keseimbangan antara kebutuhan dan masukan nutrisi (Mary, 2011:1). Status Gizi (Nutrition Status) adalah ekspresi dari keadaan keseimbangan dalam dalam bentuk variabel tertentu atau perwujudan dari nutriture dalam bentuk variabel tertentu (Ellya, 2010:1).

\section{Faktor - faktor yang mempengaruhi Status Gizi}

Menurut Supariasa, (2012) masalah gizi pada hakikatnya adalah masalah kesehatan masyarakat, namun penanggulangannya tidak dapat dilakukan dengan pendekatan medis dan pelayanan kesehatan saja. Penyebab timbulnya masalah gizi adalah multifaktor, oleh karena itu pendekatan penanggulangannya harus melibatkan berbagai sektor yang terkait, berikut merupakan faktor - faktor yang mempengaruhi status gizi, yaitu :

a. Status Sosial

Sosial adalah segala sesuatu yang mengenai masyarakat sedangkan ekonomi adalah segala usaha manusia untuk memenuhi kebutuhan untuk mencapai kemakmuran hidup.Sosial ekonomi merupakan suatu konsep dan untuk mengukur status sosial ekonomi keluarga dilihat dari variabel tingkat pekerjaan.Rendahnya ekonomi keluarga, akan berdampak dengan rendahnya daya beli pada keluarga tersebut. Selain itu rendahnya kualitas dan kuantitas konsumsi pangan, merupakan penyebab langsung dari kekurangan gizi pada anak balita.Keadaan sosial ekonomi yang rendah berkaitan dengan masalah kesehatan yang dihadapi karena ketidaktahuan dan ketidakmampuan untuk mengatasi berbagai masalah tersebut.Balita dengan gizi buruk pada umumnya hidup dengan makanan yang kurang bergizi (Soekiman,2009).

Bekerja bagi ibu mempunyai pengaruh terhadap kehidupan keluarga. Ibu yang bekerja mempunyai batasan yaitu ibu yang melakukan aktivitas ekonomi yang mencari penghasilan baik dari sektor formal atau informal yang dilakukan secara reguler di luar rumah yang akan berpengaruh terhadap waktu yang dimiliki oleh ibu untuk memberikan pelayanan terhadap anaknya.Pekerjaan tetap ibu yang mengharuskan ibu meninggalkan anaknya dari pagi sampai sore menyebabkan pemberian ASI tidak dilakukan dengan sebagaimana mestinya (Depkes RI, 2012).

Masyarakat tumbuh dengan kecenderungan bahwa orang yang bekerja akan lebih dihargai secara sosial ekonomi di masyarakat. Pekerjaan dapat dibagi menjadi pekerjaan yang berstatus tinggi yaitu antara laintenaga administrasi tata usaha, tenaga ahli teknik dan ahli jenis, pemimpin,dan ketatalaksanaan dalam suatu instansi baik pemerintah maupun swasta dan pekerjaan yang berstatus rendah antara lain petani dan operator alat angkut (Depkes RI,2012). 
b. Pengetahuan

Kurangnya pendidikan dan pengertian yang salah tentang kebutuhan pangan dan nilai pangan adalah umum dijumpai setiap negara di dunia.Kemiskinan dan kekurangan persediaan pangan yang bergizi merupakan faktor penting dalam masalah kurang gizi.Salah satu faktor yang menyebabkan timbulnya kemiskinan adalah pendidikan yang rendah. Adanya pendidikan yang rendah tersebut menyebabkan seseorang kurang mempunyai keterampilan tertentu yang diperlukan dalam kehidupan (Abu A,2010).

Rendahnya pendidikan dapat mempengaruhi ketersediaan pangan dalam keluarga, yang selanjutnya mempengaruhi kuantitasdan kualitas konsumsi pangan yang merupakan penyebab langsung dari kekurangan gizi pada anak balita (Depkes RI, 2010).Tingkat pendidikan terutama tingkat pendidikan ibu dapat mempengaruhi derajat kesehatan karena pendidikan ibu berpengaruh terhadap kualitas pengasuhan anak.Tingkat pendidikan yang tinggi membuat seseorang mudah untuk menyerap informasi dan mengamalkan dalam perilaku sehari-hari. Pendidikan adalah usaha yang terencana dan sadar untuk mewujudkan suasana dan proses pembelajaran agar peserta didik secara aktif mengembangkan potensi diri dan ketrampilan yang diperlukan oleh diri sendiri, masyarakat, bangsa,dan Negara.

Menurut Abu A, (2010) Ibu merupakan orang yang berperan penting dalam penentuan konsumsi makanan dalam keluaga khususnya pada anak balita. Pengetahuan yang dimiliki ibu berpengaruh terhadap pola konsumsi makanan keluarga.Kurangnya pengetahuan ibu tentang gizi menyebabkan keanekaragaman makanan yang berkurang. Keluarga akan lebih banyak membeli barang karena pengaruh kebiasaan, iklan, dan lingkungan. Selain itu, gangguan gizi juga disebabkan karena kurangnya kemampuan ibu menerapkan informasi tentang gizi dalam kehidupan sehari-hari.

c. Kelengkapan imunisasi

Imunisasi berasal dari kata imun yaitu resisten atau kebal. Imunisasi terhadap suatu penyakit hanya dapat memberi kekebalan terhadap penyakit tersebut sehingga bila balita kelak terpajan antigen yang sama, balita tersebut tidak akan sakit dan untuk menghindari penyakit lain diperlukan imunisasi yang lain. Infeksi pada balita penting untuk dicegah dengan imunisasi.13 Imunisasi merupakan suatu cara untuk meningkatkan kekebalan terhadap suatu antigen yang dapat dibagi menjadi imunisasi aktif dan imunisasi pasif. Imunisasi aktif adalah pemberian kuman atau racun kuman yang sudah dilemahkan atau dimatikan untuk merangsang tubuh memproduksi antibodi sendiri sedangkan imunisasi pasif adalah penyuntikan sejumlah antibodi sehingga kadar antibodi dalam tubuh meningkat (Supartini, 2010).

Sistem kekebalan tersebut yang menyebabkan balita menjadi tidak terjangkit sakit.Apabila balita tidak melakukan imunisasi, maka kekebalan tubuh balita akan berkurang dan akan rentan terkena penyakit. Hal ini mempunyai dampak yang tidak langsung dengan kejadian gizi. Imunisasi tidak cukup hanya dilakukan satu kali tetapi dilakukan secara bertahap dan lengkap terhadap berbagai penyakit untuk mempertahankan agar kekebalan dapat tetap melindungi terhadap paparan bibit penyakit.16 Macam- macam imunisasi antara lain :

a) BCG : vaksin untuk mencegah TBC yang dianjurkan diberikan saat berumur 2 bulan sampai 3 bulan dengan dosis $0,05 \mathrm{ml}$ pada bayi kurang dari 1 tahun dan $0,1 \mathrm{ml}$ pada anak disuntikkan secara intrakutan.

b) Hepatitis B : salah satu imunisasi yang diwajibkan dengan diberikan sebanyak 3 kali dengan interval 1 bulan antara suntikan pertama dan kedua kemudian 5 
bulan antara suntikan kedua dan ketiga. Usia pemberian dianjurkan sekurangkurangnya 12 jam setelah lahir.

c) Polio : imunisasi ini terdapat 2 macam yaitu vaksi oral polio dan inactivated polio vaccine.Kelebihan dari vaksin oral adalah mudah diberikan dan murah sehingga banyak digunakan.

d) DPT : vaksin yang terdiri dari toksoid difteri dan tetanus yang dimurnikan serta bakteri pertusis yang diinaktivasi.

e) Campak : imunisasi yang digunakan untuk mencegah terjadinya penyakit campak pada anak karena termasuk penyakit menular. Pemberian yang dianjurkan adalah sebanyak 2 kali yaitu pada usia 9 bulan dan pada usia 6 tahun.

f) MMR : diberikan untuk penyakit measles,mumps, danrubella sebaiknya diberikan pada usia 4 bulan sampai 6 bulan atau 9 bulan sampai 11 bulan yang dilakukan pengulangan pada usia 15 bulan-18 bulan.

g) Typhus abdominal : terdapat 3 jenis vaksin yang terdapat di Indonesia yaitu kuman yang dimatikan, kuman yang dilemahkan, dan antigen capsular Vi polysaccharida.

h) Varicella : pemberian vaksin diberikan suntikan tunggal pada usia diatas 12 tahun dan usia 13 tahun diberikan 2 kali suntikan dengan interval 4-8mg.

i) Hepatitis A:imunisasi yang digunakan untuk mencegah terjadinya hepatitis A yang diberikan pada usia diatas 2 tahun.

j) $\mathrm{HiB}$ :Haemophilusinfluenzae tipe $b$ yang digunakan untuk mencegah terjadinya influenza tipe $b$ dan diberikan sebanyak 3 kali suntikan.

k) Menurut penelitian yang dilakukan di Kabupaten Lombok Timur,imunisasi yang tidak lengkap terdapat hubungan yang bermakna dengan kejadian gizi buruk OR(95\%CI) dari 10,3; $<<0.001$ (Hidayat, 2008).

d. Penyakit infeksi

Menurut Supartani, (2010) Balita yang berada dalam status gizi buruk, umumnya sangat rentan terhadap penyakit. Seperti lingkaran setan, penyakitpenyakit tersebut justru menambah rendahnya status gizi anak.Penyakit-penyakit tersebut adalah:

a) Diare persisten : Sebagaiberlanjutnya episode diare selama 14hari atau lebih yang dimulai dari suatu diare cair akut atau berdarah (disentri). Kejadian ini sering dihubungkan dengan kehilangan berat badan dan infeksi non intestinal. Diare persisten tidak termasuk diare kronik atau diare berulang seperti penyakit sprue, gluten sensitive enteropathidan penyakit Blind loop.

b) Tuberkulosis : Tuberkulosis adalah penyakit yang disebabkan oleh Mycobacterium tuberculosis, yaitu kuman aerob yang dapat hidup terutama di paru atau di berbagai organ tubuh hidup lainnya yang mempunyai tekanan parsial oksigen yang tinggi. Bakteri ini tidak tahan terhadap ultraviolet.karena itu penularannya terjadipada malam hari. Tuberkulosis ini dapat terjadi pada semua kelompok umur, baik di paru maupun di luar paru.

c) HIV AIDS : HIV merupakan singkatan dari 'human immunodeficiencyvirus'. HIV merupakan retrovirus yang menjangkiti sel-sel sistem kekebalan tubuh manusia (terutama CD4 positive T-sel dan macrophages- komponen-komponen utama sistem kekebalan sel), dan menghancurkan atau mengganggu fungsinya. Infeksi virus ini mengakibatkan terjadinya penurunan sistem kekebalan yang terus-menerus,yang akan mengakibatkan defisiensi kekebalan tubuh.Sistem kekebalan dianggap defisien ketika sistem tersebut tidak dapat lagi menjalankan fungsinya memerangi infeksi dan penyakit- penyakit. 
Penyakit tersebut di atas dapat memperjelek keadaan gizi melalui gangguan masukan makanan dan meningkatnya kehilangan zat-zat gizi esensial tubuh.Terdapat hubungan timbal balik antara kejadian penyakit dan gizi kurang maupun gizi buruk.Anak yang menderita gizi kurang dan gizi buruk akan mengalami penurunan daya tahan, sehingga rentan terhadap penyakit. Di sisi lain anak yang menderita sakit akan cenderung menderita gizi buruk.Menurut penelitian yang dilakukan di Jogjakarta terdapat perbedaan penyakit yang bermakna antara balita KEP dengan balita yang tidak KEP(p=0,034) CI 95\% (Razak AAA dkk,2011).

e. ASI

Hanya 14\% ibu di Indonesia yang memberikan air susu ibu (ASI) eksklusif kepada bayinya sampai enam bulan. Rata-rata bayi di Indonesia hanya menerima ASI eksklusif kurang dari dua bulan. Hasil yang dikeluarkan Survei Demografi dan Kesehatan Indonesia periode 2007-2013 yang cukup memprihatinkan yaitu bayi yang mendapatkan ASI eksklusif sangat rendah.Sebanyak $86 \%$ bayi mendapatkan makanan berupa susu formula, makanan padat, atau campuran antara ASI dan susu formula. Berdasarkan riset yang sudah dibuktikan di seluruh dunia,ASI merupakan makanan terbaikbagi bayi sampai enam bulan, dan disempurnakan sampai umur dua tahun. Memberi ASIkepada bayi merupakan hal yang sangat bermanfaat antara lain oleh karena praktis, mudah, murah,sedikit kemungkinan untuk terjadi kontaminasi,dan menjalin hubungan psikologis yang erat antara bayi dan ibu yang penting dalam perkembangan psikologi anak tersebut. Beberapa sifat pada ASI yaitu merupakan makanan alam atau natural, ideal, fisiologis, nutrien yang diberikan selalu dalam keadaan segar dengan suhu yang optimal dan mengandung nutrien yang lengkap dengan komposisi yang sesuai kebutuhan pertumbuhan bayi (Supariasa, 2012).

Selain ASI mengandung gizi yang cukup lengkap, ASI juga mengandung antibodi atau zat kekebalan yang akan melindungi balita terhadap infeksi. Hal ini yang menyebabkan balita yang diberi ASI, tidak rentan terhadap penyakit dan dapat berperan langsung terhadap status gizi balita.Selain itu, ASI disesuaikan dengan sistem pencernaan bayi sehingga zat gizi cepat terserap. Berbeda dengan susu formula atau makanan tambahan yang diberikan secara dini pada bayi. Susu formula sangat susah diserap usus bayi. Pada akhirnya, bayi sulit buang air besar. Apabila pembuatan susu formula tidak steril, bayi akan rawan diare.

f. Inisiasi MenyusuiDini

Pencapaian 6 bulan ASI Eksklusif bergantung pada keberhasilan inisiasi dalam satu jam pertama. ASI Eksklusif selama 6 bulan pertama kehidupan, bersamaan dengan pemberian makanan pendamping ASI dan meneruskan ASI dari 6 bulan sampai 2 tahun, dapat mengurangi sedikitnya 20\% kematian anak balita.

Penelitian Fika dan Syafiq (2008) yang mengaitkan antara IMD dengan kesuksesan ASI Eksklusif yang menyatakan bahwa bayi yang diberi kesempatan menyusu dini dengan meletakan bayi sampai terjadi kontak kulit ke kulit ibu setidaknya selama 1 jam, hasilnya 2 kali lebih lama disusui. Pada usia enam bulan dan setahun, bayi yang diberi kesempatan untuk menyusu dini hasilnya 59\% dan $38 \%$, sedangkan bayi yang tidak diberi kesempatan menyusu dini pada umur yang sama sebesar $29 \%$ dan $8 \%$ yang masih disusui.

\section{METODE PENELITIAN}

Jenis penelitian yang digunakan dalam penelitian ini adalah jenis penelitian Analitik - observasional dengan pendekatan Case-control. Hipotesis Penelitian dengan H1: Balita yang memiliki riwayat penyakit infeksi memiliki risiko kejadian gizi kurang, Balita yang tidak ASI eksklusif memiliki risiko kejadian gizi kurang, Balita yang tidak diberi IMD 
segera setelah lahir memiliki risiko kejadian gizi kurang. Variabel pada penelitian ini adalah variabel independen (variable bebas) antara lain Riwayat Penyakit Infeksi, ASI eksklusif dan IMD dan Variabel dependen (variable terikat) kejadian gizi kurang pada balita di Desa Gayaman Kecamatan Mojoanyar Kabupaten Mojokerto dengan jumlah sampel sebanyak 20 orang sebagai kelompok kasus dan 20 sebagai kelompok control. Penelitian dilakukan pada bulan September 2015. Pengaruh Riwayat Penyakit Infeksi, ASI eksklusif dan IMD terhadap kejadian gizi kurang dianalisis menggunakan regresi ganda logistic.

\section{HASIL PENELITIAN}

1. Risiko kejadian gizi kurang pada balita yang memiliki riwayat penyakit infeksi

Data tentang risiko kejadian gizi kurang pada balita yang memiliki penyakit infeksi di Desa Gayaman, Kecamatan Mojoanyar, Kabupaten Mojokerto dapat dilihat pada tabel distribusi frekuensi di bawah ini.

Tabel 9 Distribusi Frekuensi Berdasarkan Risiko Kejadian Gizi Kurang Pada Balita yang Memiliki Riwayat Penyakit Infeksi

\begin{tabular}{|c|c|c|c|c|c|}
\hline \multicolumn{3}{|c|}{ Keterangan } & \multicolumn{2}{|c|}{ Status_gizi } & \multirow[b]{2}{*}{ Total } \\
\hline & & & kurang baik & baik & \\
\hline \multirow[t]{6}{*}{ infeksi } & \multirow[t]{3}{*}{ tidak } & Jumlah & 2 & 20 & 22 \\
\hline & & $\%$ & $9.1 \%$ & $90.9 \%$ & $100.0 \%$ \\
\hline & & Total & $5.0 \%$ & $50.0 \%$ & $55.0 \%$ \\
\hline & \multirow[t]{3}{*}{ ya } & Jumlah & 18 & 0 & 18 \\
\hline & & $\%$ & $100.0 \%$ & $.0 \%$ & $100.0 \%$ \\
\hline & & Total & $45.0 \%$ & $.0 \%$ & $45.0 \%$ \\
\hline \multirow{3}{*}{\multicolumn{2}{|c|}{ Total }} & Jumlah & 20 & 20 & 40 \\
\hline & & $\%$ & $50.0 \%$ & $50.0 \%$ & $100.0 \%$ \\
\hline & & Total & $50.0 \%$ & $50.0 \%$ & $100.0 \%$ \\
\hline \multicolumn{6}{|c|}{$\begin{array}{c}\text { Nilai } X^{2} \text { hitung }=32,727 \text { dan } p \text { value }=0,000 \\
\text { Nilai } O R=1,85\end{array}$} \\
\hline
\end{tabular}

Tabel diatas menjelaskan bahwa responden yang memiliki status gizi yang baik semuanya tidak mempunyai riwayat penyakit infeksi dalam 1 bulan terakhir, sedangkan responden yang memiliki status gizi kurang baik dalam 1 bulan terakhir sebagian besar pernah menderita penyakit tertentu diantaranya diare, flu, batuk, dan demam. Hasil uji chi square menjelaskan bahwa ada pengaruh yang sangat signifikan riwayat infeksi terhadap kejadian gizi kurang. Hasil analisa regresi logistic menjelaskan bahwa balita yang memiliki riwayat penyakit infeksi dalam 1 bulan terakhir beresiko 1,85 kali lebih tinggi memiliki status gizi kurang baik dibandingkan balita yang tidak memiliki riwayat penyakit infeksi dalam 1 bulan terakhir.

2. Risiko kejadian gizi kurang pada balita yang diberi ASI ekslusif

Data tentang risiko kejadian gizi kurang pada balita yang diberi ASI ekslusif di Desa Gayaman, Kecamatan Mojoanyar, Kabupaten Mojokerto dapat dilihat pada tabel distribusi frekuensi di bawah ini. 
Tabel 10 Distribusi Frekuensi Berdasarkan Risiko Kejadian Gizi Kurang Pada Balita Yang Diberi ASI Ekslusif

\begin{tabular}{|c|c|c|c|c|c|}
\hline \multicolumn{3}{|c|}{ Keterangan } & \multicolumn{2}{|c|}{ Status_gizi } & \multirow[b]{2}{*}{ Total } \\
\hline & & & kurang baik & baik & \\
\hline \multirow[t]{6}{*}{ ASI } & \multirow[t]{3}{*}{ eksklusif } & Jumlah & 7 & 14 & 21 \\
\hline & & $\%$ & $33.3 \%$ & $66.7 \%$ & $100.0 \%$ \\
\hline & & Total & $17.5 \%$ & $35.0 \%$ & $52.5 \%$ \\
\hline & \multirow[t]{3}{*}{ tidak eksklusif } & Jumlah & 13 & 6 & 19 \\
\hline & & $\%$ & $68.4 \%$ & $31.6 \%$ & $100.0 \%$ \\
\hline & & Total & $32.5 \%$ & $15.0 \%$ & $47.5 \%$ \\
\hline \multirow{3}{*}{\multicolumn{2}{|c|}{ Total }} & Jumlah & 20 & 20 & 40 \\
\hline & & $\%$ & $50.0 \%$ & $50.0 \%$ & $100.0 \%$ \\
\hline & & Total & $50.0 \%$ & $50.0 \%$ & $100.0 \%$ \\
\hline
\end{tabular}

Nilai $X^{2}$ hitung $=4,912$ dan $p$ value $=0,027$

Nilai OR $=1,47$

Hasil penelitian menunjukkan bahwa responden yang mendapatkan ASI eksklusif sebagian besar memiliki status gizi yang baik, sedangkan responden yang tidak mendapatkan ASI eksklusif sebagian besar memiliki status gizi yang kurang baik. Hasil dari uji chi square disimpulkan bahwa ada pengaruh yang signifikan pemberian ASI eksklusif terhadap kejadian gizi kurang baik, sedangkan hasil uji regresi logistic diketahui bahwa responden yang tidak mendapatkan ASI eksklusif memiliki resiko 1,47 kali lebih besar mengalami kejadian gizi kurang baik

3. Risiko kejadian gizi kurang pada balita yang diinisiasi menyusui dini (IMD) sesaat setelah lahir

Data tentang risiko kejadian gizi kurang pada balita yang di Inisiasi Menusui Dini (IMD) sesaat setelah lahir di Desa Gayaman, Kecamatan Mojoanyar, Kabupaten Mojokerto dapat dilihat pada tabel distribusi frekuensi di bawah ini.

Tabel 11 Distribusi Frekuensi Berdasarkan Risiko Kejadian Gizi Kurang Pada Balita yang Di Inisiasi Menyusui Dini (IMD) Sesaat Setelah Lahir

\begin{tabular}{|c|c|c|c|c|c|}
\hline \multirow{2}{*}{\multicolumn{3}{|c|}{ Keterangan }} & \multicolumn{2}{|c|}{ Status_gizi } & \multirow{3}{*}{$\begin{array}{l}\text { Total } \\
21\end{array}$} \\
\hline & & & \multirow{2}{*}{$\begin{array}{r}\text { kurang baik } \\
6\end{array}$} & \multirow{2}{*}{$\begin{array}{r}\text { baik } \\
\\
15\end{array}$} & \\
\hline \multirow[t]{6}{*}{ IMD } & \multirow[t]{3}{*}{ ya } & Jumlah & & & \\
\hline & & $\%$ & $28.6 \%$ & $71.4 \%$ & $100.0 \%$ \\
\hline & & Total & $15.0 \%$ & $37.5 \%$ & $52.5 \%$ \\
\hline & \multirow[t]{3}{*}{ tidak } & Jumlah & 14 & 5 & 19 \\
\hline & & $\%$ & $73.7 \%$ & $26.3 \%$ & $100.0 \%$ \\
\hline & & Total & $35.0 \%$ & $12.5 \%$ & $47.5 \%$ \\
\hline \multirow[t]{3}{*}{ Total } & & Jumlah & 20 & 20 & 40 \\
\hline & & $\%$ & $50.0 \%$ & $50.0 \%$ & $100.0 \%$ \\
\hline & & Total & $50.0 \%$ & $50.0 \%$ & $100.0 \%$ \\
\hline \multicolumn{6}{|c|}{$\begin{array}{c}\text { Nilai } X^{2} \text { hitung }=8,120 \text { dan } p \text { value }=0,004 \\
\text { Nilai } O R=1,46\end{array}$} \\
\hline
\end{tabular}


Tabel 11 menjelaskan bahwa responden yang mendapatkan inisiasi menyusu dini setelah dilahirkan sebagian besar memiliki status gizi yang baik sedangkan responden yang tidak mendapatkan IMD sebagian besar memiliki status gizi yang kurang baik. Hasil uji chi square menjelaskan bahwa ada pengaruh yang sangat signifikan pemberian IMD terhadap status gizi anak. Responden yang tidak mendapatkan IMD memiliki resiko 1,46 kali lebih besar mengalami kejadian gizi kurang dibandingkan yang mendapatkan IMD.

\section{E. PEMBAHASAN}

1. Risiko Kejadian Gizi Kurang Pada Balita Ditinjau Dari Riwayat Penyakit Infeksi

Hasil penelitian menunjukkan bahwa riwayat penyakit infeksi merupakan faktor resiko kejadian gizi kurang baik pada balita. Supartani (2009) menyebutkan bahwa penyakit infeksi yang menyerang balita secara tidak langsung dapat berpengaruh terhadap status gizi balita tersebut. Beberapa Balita dapat menderita gizi kurang karena mengalami penyakit atau kondisi tertentu yang menyebabkan tubuh tidak mampu untuk mencerna ataupun menyerap makanan secara sempurna. Contohnya pada penderita penyakit seliak yang mengalami gangguan pada saluran pencernaan yang dipicu oleh sejenis protein yang banyak terdapat pada tepung yaitu gluten. Penyakit seliak ini mempengaruhi kemampuan tubuh untuk menyerap nutrisi sehingga terjadi defisiensi. Bayi baru lahir sampai berusia tiga tahun merupakan kelompok kritis untuk tumbuh kembang. Jika orangtua tidak mencukupi kebutuhan zat gizi yang diperlukan tubuh, bayi bisa mengalami gangguan pertumbuhan. Selain itu di usia batita ini anak lebih sering mengalami gangguan kesehatan dan rentan terhadap berbagai penyakit infeksi yang berdampak besar terhadap tumbuh kembang anak. Itulah sebabnya anak usia ini membutuhkan pola makan bergizi seimbang untuk memenuhi kebutuhan gizinya sehingga mereka memiliki daya tahan tubuh yang baik sekaligus mengoptimalkan kecerdasannya

Hasil penelitian yang dilakukan oleh peneliti didapatkan antara teori dan fakta tidak sesuai, sebab riwayat penyakit infeksi bukan merupakan faktor resiko kejadian gizi kurang pada balita. Riwayat penyakit infeksi yang terjadi pada balita bukan merupakan factor resiko terjadinya Gizi Kurang karena bayi yang mempunyai riwayat BBLR membutuhkan waktu dan proses perbaikan gizi yang ekstra untuk memulihkan status gizinya Selain itu balita yang mengalami gizi kurang justru akan memperburuk keadaan sepeti mudah terserang penyakit infeksi.

2. Risiko Kejadian Gizi Kurang Pada Balita Ditinjau Dari Pemberian ASI Ekslusif

Hasil penelitian menunjukkan bahwa riwayat ASI Ekslusif merupakan factor resiko terjadinya gizi kurang pada balita. Menurut Azisya (2010) ASI merupakan sumber energi utama sehingga hanya dengan pemberian ASI eksklusif yang di lakukan secara efektif kebutuhan nutrisi bayi dapat terpenuhi dan diberikan pada bayi berumur 0 sampai 6 bulan. Pemberian ASI ekslusif yang dilakukan secara infektif dapat memenuhi kebutuhan nutrisi balita. Menurut Supariasa (2009) ASI juga memiliki manfaat sebagai antibody dan imunisasi pasif. Dengan ASI ekslusif balita akan terlindungi dari penyakit. Jika balita sehat maka proses tumbuh kembang balita akan optimal. Kebutuhan bayi usia 0-6 bulan jika sudah tercukupi dari ASI, setelah itu mereka memerlukan makanan pendamping ASI (MPASI) sebagai persiapan peralihan menuju makanan keluarga. MPASI biasanya berupa sumber karbohidrat yang dibuat lembek dan dilengkapi protein hewani dan nabati serta sayur. Konsumsi yang cukup adalah makanan yang baik jumlah dan kualitasnya akan menjamin pertumbuhan dan perkembangan anak, jumlahnya cukup dan bervariasi menunya. Keragaman makanan anak setiap hari harus memenuhi akan makanan pokok, lauk pauk, sayuran, dan buah. 
Menurut Ridzal, Hadju, Rochimiwati (2013) tidak adanya hubungan Antara Pemberian ASI Esklusif dengan status gizi anak usia 6-23 bulan tersebut biasa jadi disebabkan oleh banyak faktor disaat anak sudah berusia $>6$ bulan; Diantaranya dipengaruhi oleh sanitasi lingkungan yang tidak mendukung, kemampuan atau pengetahuan ibu yang kurang terhadap pemberian ASI Esklusif, jenis dan pemberian MP-ASI yang terlalu dini ataupun terlambat.

Hasil penelitian ini sejalan dengan hasil dari penelitian Wibowo tentang Pengaruh Pemberian ASI Eksklusif Terhadap Gizi Pada Bayi Usia 6 Bulan di Kecamatan Mampang Perapatan Tahun 2009 yaitu status gizi bayi yang tidak di berikan ASI eksklusif, yang termasuk kedalam kategori gizi buruk sebanyak 3 bayi $(3,1 \%)$ sementara yang termasuk kedalam kategori gizi kurang sebanyak 8 bayi $(8,5 \%)$. Sementara status gizi bayi yang diberikan ASI eksklusif tidak ada yang termasuk kedalam kategori gizi buruk. Hal tersebut menunjukkan bahwa terdapat pengaruh pemberian ASI eksklusif terhadap status gizi bayi. ASI merupakan makanan yang mengandung nutrient yang paling lengkap dan sempurna. Semua nutrisi yang dibutuhkan oleh bayi terkandung dalam ASI sekaligus juga zat kekebalan yang terdapat di dalam ASI. Oleh sebab itu bayi yang mendapatkan ASI eksklusif memiliki pertumbuhan yang jauh lebih baik daripada yang tidak mendapatkan ASI eksklusif.

3. Risiko Kejadian Gizi Kurang Pada Balita Ditinjau Dari Inisiasi Menyusui Dini

Hasil penelitian menjelaskan bahwa IMD merupakan faktor resiko terhadap kejadian gizi kurang baik. Supariasa (2012) mengatakan kegagalan Inisiasi Menyusui Dini akan berpengaruh pada produksi ASI. Jika terjadi ketidak seimbangan antara produksi ASI ibu dan kebutuhan ASI yang diperlukan bayi maka akan berakibat kegagalan program ASI ekslusif . Sehingga kebutuhan gizi bayi tidak dapat terpenuhi dengan baik. Menurut Suryoprajogo (dalam Dinartiana dan Sumini, 2011) Bayi yang diberi kesempatan menyusu dini lebih berhasil menyusui eksklusif dan akan lebih lama disusui. Karena makanan awal non-ASI umumnya mengandung zat putih telur yang bukan berasal dari susu manusia, misalnya dari susu hewan. Hal ini dapat mengganggu pertumbuhan fungsi usus dan mencetuskan alergi lebih awal. Selain itu dengan posisi bayi berada di atas perut ibu maka akan terjadi hentakan kepala bayi ke dada ibu, sentuhan tangan bayi di puting susu dan sekitarnya, emutan, dan jilatan bayi pada puting ibu merangsang pengeluaran hormon oksitosin.

Hasil penelitian ini sejalan dengan hasil penelitian Meiliani, dkk (2011) yang menunjukkan bahwa bayi yang tidak mendapatkan IMD dalam satu jam pertama kehidupannya lebih banyak menderita gizi kurang pada saat berusia enam bulan $(65,2 \%)$. Artinya, IMD merupakan faktor risiko statu gizi kurang pada bayi usia enam bulan. Terdapat teori yang mendukung hasil penelitian itu yaitu IMD, kontak kulit ibu dan bayi segera setelah lahir dan bayi menyusu sendiri dalam satu jam pertama kehidupan, memiliki manfaat untuk kelangsungan hidup bayi (Suryoprayogo, 2009). Air susu ibu meningkatkan kelangsungan hidup bayi, kesehatan, otak, dan perkembangan motorik. IMD memiliki peranan penting terhadap status gizi seorang bayi dalam enam bulan pertama kehidupan karena membentuk ikatan kasih sayang antar ibu dan bayi yang dapat memberikan kehangatan kepada bayi sehingga pada umumnya bayi akan lebih berhasil menyusu secara eksklusif karena merangsang produksi ASI dan bayi dapat tidur dalam waktu yang lama. Isapan bayi diketahui meningkatkan hormon prolaktin dan oksitosin sehingga memperbanyak produksi ASI. Dengan asupan nutrisi yang cukup dan lingkungan yang mendukung untuk bayi tidur lama maka energi yang masuk dapat dipakai untuk pertumbuhan yang optimal. 
Namun hasil penelitian ini tidak sejalan dengan Ridzal, Hadju, Rochimiwati (2013) yang menyatakan bahwa tidak adanya hubungan antara status IMD dengan status gizi hal ini disebabkan adanya faktor lain yang mempengaruhi status gizi anak pada usia baduta seperti lingkungan sekitar rumah yang kurang bersih, prilaku hidup yang tidak higienis sehingga dapat menyebabkan anak sakit pada waktu tertentu. Demikian halnya dengan dengan penelitian yang dilakukan oleh Susanty (dalam Ridzal, Hadju, Rochimiwati, 2013) di kelurahan Kaluku Bodoa Kecamatan Tallo yang menyatakan bahwa tidak ada hubungan yang bermakna antara Status IMD dengan Status gizi anak usia 6-24 bulan yang disebabkan faktor lain seperti lingkungan yang kotor dan prilaku hidup yang tidak bersih.

4. Resiko kejadian gizi kurang pada balita ditinjau dari riwayat Penyakit Infeksi, ASI Ekslusif, dan IMD.

Hasil penelitian menjelaskan bahwa diantara pemberian IMD, ASI eksklusif dan riwayat penyakit infeksi, maka faktor yang paling dominan dalam menentukan kejadian gizi kurang pada balita adalah riwayat penyakit infeksi. Hubugan antara status gizi dengan riwayat infeksi seringkali berupa hubungan timbal balik. Penyakit infeksi yang kronis mampu membuat seseorang tidak bias mencerna dengan baik makanan yang dikonsumsi sehingga tubuh pada akhirnya kekurangan nutrisi yang dalam jangka waktu lama mampu menyebabkan terjadinya malnutrisi. Orang sakit lebih rentan terhadap gangguan diare, malabsorpsi, hilangnya selera makan, diversi nutrisi untuk respon kekebalan, dan hilangnya nitrogen pada urin, yang kesemuanya menyebabkan kekurangan nutrisi dan kemudian merusak mekanisme pertahanan. Rangkaian kejadian ini pada gilirannya menyebabkan semakin rendahnya asupan makanan. Selain itu, demam yang sering pula ikut terjadi akan membuat penderita memerlukan lebih banyak energi dan mikronutrisi (Widodo, 2012)

Salah satu penyakit infeksi yang menyebabkan malnutrisi pada balita adalah diare. Sepanjang tahun 2014 terdapat 2549 kasus diare dengan tingkat Case Fatality Rate (CFR) sebesar 1,14 yang merupakan jumlah kasus tertinggi dibandingkan tahun 2012 dan 2013. Selain itu diare masih mendominasi urutan pertama penyakit infeksi yang paling banyak diderita oleh pasien RS di seluruh Indonesia (Wijaya, 2015).

Diare merupakan penyebab utama dari malnutrisi. Setiap episode diare dapat menyebabkan kehilangan berat badan (Tanchoco,2006). Semakin buruk keadaan gizi anak, semakin sering dan semakin berat diare yang dideritanya.(Suharyono, 2007). Ada 2 masalah yang berbahaya dari diare, yaitu kematian dan malnutrisi. Diare dapat menyebabkan malnutrisi dan membuat lebih buruk lagi karena pada diare tubuh akan kehilangan nutrien, anak-anak dengan diare mungkin merasa tidak lapar serta ibu tidak memberi makan pada anak ketika mengalami diare (WHO, 2005). Mekanisme yang menyebabkan timbulnya diare ialah gangguan osmotik, gangguan sekresi, dan gangguan motilitas usus (Suraatmaja, 2007). Dasar semua diare adalah gangguan transportasi larutan usus, perpindahan air melalui membran usus berlangsung secara pasif dan hal ini ditentukan oleh aliran larutan secara aktif maupun pasif, terutama natrium, klorida dan glukosa (Ulshen, 2000). Penelitian yang dilakukan oleh Rusmiati di RSU Dr.Tengku Mansyur Tanjungbalai Medan mendapatkan adanya hubungan antara lamanya kejadian diare dengan status gizi balita menurut BB/U (Rusmiati,2008). Sebagian besar ibu juga melakukan tindakan yang cepat dalam menanggulangi diare dengan membawa berobat ke tempat pelayanan kesehatan seperti bidan/dokter $(75,7 \%)$ dan memberikan oralit/cairan rumah tangga $(5,4 \%)$. Tindakan tersebut akan memperkecil terjadinya gangguan keseimbangan elektrolit pada anak karena prinsip utama dalam pengobatan diare akut adalah rehidrasi (Petri,2008). Frekuensi diare yang jarang, durasi diare singkat, serta pemberian tindakan 
penanggulangan yang tepat menyebabkan diare yang terjadi tidak mempengaruhi status gizi balita secara bermakna.

Namun malnutrisi juga merupakan penyebab terjadinya penyakit infeksi pada balita. Asupan makanan yang tidak memadai menyebabkan turunnya berat badan, menurunnya kekebalan, invasi oleh patogen, dan gangguan pertumbuhan dan perkembangan pada anak. Oleh sebab itu anak yang mengalami malnutrisi lebih rentan untuk terinfeksi virus, bakteri bahkan parasit.

\section{F. PENUTUP}

1. Simpulan

Berdasarkan hasil penelitian disimpulkan bahwa faktor riwayat infeksi, pemberian ASI eksklusif dan riwayat pemberian Inisiasi Menyusu Dini (IMD) merupakan faktor resiko kejadian gizi kurang pada balita.

2. Saran

Bagi ibu diharapkan meningkatkan pengetahuannya khususnya tentang pemenuhan nutrisi bagi balita dan aktif bertanya kepada tenaga kesehatan tentang hal-hal yang belum dimengerti sedangkan bagi peneliti selanjutnya diharapkan Jika melakukan penelitian tentang riwayat penyakit infeksi, ASI Ekslusif, IMD sebaiknya menggunakan riwayat yang lebih lama (kurang lebih 3-4 tahun terakhir) dan memperluas faktor penyebab malnutrisi yang lainnya seperti faktor social ekonomi dan budaya masyarakat.

\section{DAFTAR PUSTAKA}

Abu A. 1997.Ilmu Sosial Dasar.Jakarta:Rineka Cipta..

Almatsier S. 2001. Prinsip Dasar Ilmu Gizi. Jakarta: Gramedia Pustaka Utama.

Almatsier S.2009.Prinsip Dasar Ilmu Gizi. Jakarta: Gramedia Pustaka Utama.

Anwar K,Juffrie M,Julia M.Faktor Risiko Kejadian Gizi Buruk di Kabupaten Lombok Timur,

Propinsi Nusa Tenggara Barat.Jurnal Gizi Klinik Indonesia [Internet].2005[cited 2011

Desember 14]:2(3):81-85.Available from:http://ijcn.or.id/v2/content/view/33/40/

Arikunto S.2009.Prosedur Penelitian Suatu Pendekatan Praktik.Jakarta : PT Asdi Mahasatya. Departemen Kesehatan RI, 2002.Program Gizi Makro.Jakarta:Depkes RI.

Departemen Kesehatan RI. 2004. Analisis Situasi dan Kesehatan Masyarakat. Jakarta:Depkes RI

Departemen Kesehatan RI.Pemantauan Pertumbuhan Balita. 2012. Jakarta: Direktorat Gizi Departemen Kesehatan RI.

Dinartiana, Amalia\&Sumini, Ni Luh. 2011.Hubungan Pelaksanaan Inisiasi Menyusu Dini Dengan Keberhasilan Pemberian ASI Eksklusif Pada Ibu Yang Mempunyai Bayi Usia 7-12 Bulan di Kota Semarang.Vol. 1 no. 2. (http://library.usu.ac.id, diakses 12 April 2014)

Dini L.Konsumsi Pangan Tingkat Rumah Tangga Sebelum dan Selama Krisis Ekonomi.Jakarta:PT Gramedia Pustaka;2000.

Faiza R, Elnovriza D, Syafianti.Faktor Risiko Kejadian Gizi Buruk pada Anak Balita di Wilayah Kerja Puskesmas Andalas Kecamatan Padang Timur Kota Padang.Jurnal Media Gizi Keluarga [Internet].2007 [cited 2012 Juni1]:31(1):80-88.Available from: http://isjd.pdii.lipi.go.id/admin/jurnal/311078088

Hidayat AAA.2008. Pengantar Ilmu Kesehatan Anak untuk Pendidikan Kebidanan. Jakarta:Salemba Medika. .

Hidayat AAA.2011. Pengantar Ilmu Kesehatan Anak untuk Pendidikan Kebidanan Jakarta :

Salemba Medika 
Kusriadi.Analisis Faktor Risiko Yang Mempengaruhi Kejadian Kurang Gizi Pada Anak Balita Di Provinsi Nusa Tenggara Barat (NTB)[karya tulis ilmiah].Bogor: Institut Pertanian Bogor; 2010.

Lada C, Aspatria U, Jutomo L. Kajian Jenis-Jenis Penyakit Infeksi dan Lamanya Perawatan Bagi Balita Penderita Gizi Buruk di Panti Rawat Gizi Panite Kabupaten Timor Tengah Selatan.Jurnal Gizi Klinik Indonesia [Internet].2007 [cited 2012 Mei 25]: 2(2): 1-5. Available from: http://isjd.pdii.lipi.go.id/admin/jurnal/1109819_2085-9341.pdf

Lingga NK.Faktor yang Berhubungan dengan Status Gizi Anak Balita di Desa Kolam Kecamatan Percut Sei Tuan Kabupaten Deli Serdang [karya tulis ilmiah]. Medan:Universitas Sumatera Utara;2010.

Mexitalia M. Air Susu Ibu dan Menyusui. Dalam: Sjarif DR, Lestari ED, Mexitalia M, Nasar SS, penyunting. Buku Ajar Nutrisi Pediatrik dan Penyakit Metabolik. Edisi ke1.Jakarta: IDAI;2011. hal. 77-95.

Nadimin. Hubungan Keluarga Sadar Gizi dengan Status Gizi Balita di Kabupaten Takalar Sulawesi Selatan. Jurnal Media Gizi Pangan [Internet].2010 [cited 2012 Mei 28]:10(2):1-7. Available from: http://jurnalmediagizipangan.files.wordpress.com/2012/04/1-hubungan-keluargasadar-gizi-dengan-statu s-gizi-balita

Notoatmodjo S. Prinsip-Prinsip Dasar IlmuKesehatan Masyarakat.Jakarta : Rineka Cipta; 2003.

Novita sari, Dewi. 2005. Faktor Faktor Risiko Kejadian Gizi Buruk Pada Balita Yang Dirawat Di RSUP dr. Kariadi Semarang. Jurnal Gizi Klinik Indonesia [Internet]. [cited 2012 Mei 25]: 2(1): 80-84. Available from: (http://dc183.4shared.com/doc/gV1MYaob/preview. Diakses 12 Maret 2014)

Pudjiadi S.2005. Ilmu Gizi Klinis Pada Anak. Jakarta: Gaya Baru.

Razak AA,Gunawan IMA,Budiningsari RD. 2011, Pola Asuh Ibu Sebagai Faktor Risiko Kejadian Kurang Energi Protein (KEP) Pada Anak Balita.Jurnal Gizi Klinik Indonesia[Internet].2009[cited 2011 Desember 14]:6(2):95-103.Available from: http://www.i-lib.ugm.ac.id/jurnal/download.php?dataId=10761

Retno S.Faktor yang Berhubungan dengan Status Gizi Balita Setelah Mendapatkan PMT Pemulihan di Provinsi DKI Jakarta [karya tulis ilmiah]. Jakarta: Universitas Indonesia; 2008.

Rumiasih. Beberapa Faktor yang Berhubungan dengan Status Gizi Buruk pada Anak Balita di Kabupaten Magelang[karya tulis ilmiah].Semarang: Universitas Diponegoro;2003.

Rusmiati. 2008. Gambaran pola konsumsi pangan dan status gizi anak balita penderita diare di ruang anak RSU Dr. Tengku Mansyur Tanjungbalai tahun 2008 (skripsi). Medan: Universitas Sumatera Utara; 2008.

Soekanto,Soerjono.2000. Sosiologi Suatu Pengantar. Jakarta: Raja Grafindo Persada.

Soekirman. 2000. Ilmu Gizi dan Aplikasinya untuk Keluarga dan Masyarakat.Jakarta:EGC.

Soendjojo RD,Sritje H,Mien S.Menstimulasi Anak 0-1 Tahun.Jakarta:PT Elexmedia Komputindo.2000.

Staf Pengajar Ilmu Kesehatan Anak FK Universitas Indonesia.Buku Kuliah Ilmu Kesehatan Anak.Jakarta:Infomedika;2007.

Sudaryat S, Soetjiningsih. 2010. Pedoman Diagnosis dan Terapi Ilmu Kesehatan Anak RSUP Sanglah.Denpasar: Denpasar. SMF Ilmu Kesehatan Anak FK Unud.

Sudaryat S, Soetjiningsih.Pedoman Diagnosis dan Terapi Ilmu Kesehatan Anak RSUP Sanglah.Denpasar:SMF Ilmu Kesehatan Anak FK Unud Denpasar; 2000.

Suharyono, 2007 . Diare akut : Klinik dan laboratorik. Jakarta : Rineka Cipta.

Sumiati I. Evaluasi Penatalaksanaan Asuhan Gizi pada Balita Kurang Energi Protein di RSUD Ulin Banjarmasin [karya tulis ilmiah]. Malang: Universitas Brawijaya; 2007. 
Supariasa, I. 2012. Penilaian Status Gizi. Buku Kedokteran: EGC.

Supartini Y 2002.Buku Ajar Konsep Dasar Keperawatan Anak.Jakarta:EGC.

Supartini Y.2009. Buku Ajar Konsep Dasar Keperawatan Anak.Jakarta:EGC.

Suraatmaja, S., 2007, Diare Akut, Kapita Selekta Gasroenterologi Anak, Cetakan ke2, Sagung Seto, Denpasar, 1-24.

Susanti E. Hubungan Berat Badan Lahir dengan Status Gizi Balita di Wilayah Kerja Puskesmas Basuki Rahmad Kota Bengkulu [karya tulis ilmiah]. Bengkulu:Universitas Bengkulu

Tanchoco, C.C., et al. 2006. Diet Supplemented With BCT Oil In The Management Of Childhood Diarrhea. Available from: http://www.ncbi.nlm.nih.gov/pubmed/17468085\%5BAccessed 8 Maret 2010

Ulshen, Martin, 2000. Manifestasi Klinis Penyakit Saluran Pencernaan. In: Behrman, Kliegman \& Arvin, Nelson, ed. Ilmu Kesehatan Anak vol. 2 Edisi 15. Jakarta: EGC, 1273-1274.I

Walker,Allan.Pediatric Gastrointertinal Disease.USA:DC Decker;2004.

Widodo, Setiyo, 2012. Malnutrisi dan Penyakit Infeksi. Dalam http:// setiyowidodo.blogspot.co.id disitasi tanggal 19 September 2012.

Wijaya, Awi Muliadi, 2015. Data (angka) diare di Indonesia. Dalam http://www.infodokterku.com. Tanggal sitasi 18 Juni 2015.

World Health Organisation.Pelayanan Kesehatan Anak di Rumah Sakit.Jakarta: WHO Indonesia; 2012 